\title{
Correction to: On Finite Generability of Clones of Finite Posets
}

\section{Ádám Kunos ${ }^{1}$ · Miklós Maróti ${ }^{1}$. László Zádori ${ }^{1}$}

Published online: 10 May 2019

(C) The Author(s) 2019

\section{Correction to: Order \\ https://doi.org/10.1007/s11083-019-09486-3}

The article On Finite Generability of Clones of Finite Posets, written by Ádám Kunos, Miklós Maróti, and László Zádori was originally published electronically on the publisher's internet portal (currently SpringerLink) on April 04, 2019 without open access.

With the author(s)' decision to opt for Open Choice the copyright of the article changed on April 2019 to (CThe Author(s) 2019 and the article is forthwith distributed under the terms of the Creative Commons Attribution 4.0 International License (http:// creativecommons.org/licenses/by/4.0/), which permits use, duplication, adaptation, distribution and reproduction in any medium or format, as long as you give appropriate credit to the original author(s) and the source, provide a link to the Creative Commons license and indicate if changes were made.

Open Access This article is distributed under the terms of the Creative Commons Attribution 4.0 International License (http://creativecommons.org/licenses/by/4.0/), which permits use, duplication, adaptation, distribution and reproduction in any medium or format, as long as you give appropriate credit to the original author(s) and the source, provide a link to the Creative Commons license and indicate if changes were made.

The original article has been corrected.

Publisher's Note Springer Nature remains neutral with regard to jurisdictional claims in published maps and institutional affiliations.

The online version of the original article can be found at https://doi.org/10.1007/s11083-019-09486-3.

Ádám Kunos

akunos@math.u-szeged.hu

Miklós Maróti

mmaroti@math.u-szeged.hu

László Zádori

zadori@math.u-szeged.hu

1 Bolyai Institute, University of Szeged, Aradi vértanúk tere 1, Szeged, 6720, Hungary 